\title{
Intracellular pH regulation in human Sertoli cells: role of membrane transporters
}

\author{
P F Oliveira ${ }^{1}$, M Sousa ${ }^{1,2}$, A Barros $^{3}$, T Moura $^{4}$ and A Rebelo da Costa ${ }^{1,5}$ \\ ${ }^{1}$ UMIB, Instituto de Ciências Biomédicas de Abel Salazar (ICBAS), Universidade do Porto, L. Prof. Abel Salazar, 2, \\ 4099-003 Porto, Portugal, ${ }^{2}$ Laboratório de Biologia Celular, ICBAS-UP, 4099-003 Porto, Portugal, ${ }^{3}$ Departamento de \\ Genética, FM-UP, 4200-319 Porto, Portugal, ${ }^{4}$ REQUIMTE, Departamento de Química, FCT-UNL, 2829-516 Caparica, \\ Portugal and ${ }^{5}$ Laboratório de Fisiologia Geral, ICBAS-UP, 4099-003 Porto, Portugal
}

Correspondence should be addressed to P F Oliveira who is now at Laboratório de Fisiologia dos Gâmetas e Transporte lónico, ICBAS, LNIV (ala H), Rua dos Lagidos, Lugar da Madalena, 4485-655 Vairão, Vila do Conde, Portugal;

Email: transp.bio@mail.icav.up.pt

\begin{abstract}
Sertoli cells are responsible for regulating a wide range of processes that lead to the differentiation of male germ cells into spermatozoa. Intracellular $\mathrm{pH}(\mathrm{pHi})$ is an important parameter in cell physiology regulating namely cell metabolism and differentiation. However, pHi regulation mechanisms in Sertoli cells have not yet been systematically elucidated. In this work, pHi was determined in primary cultures of human Sertoli cells. Sertoli cells were exposed to weak acids, which caused a rapid acidification of the intracellular milieu. pHi then recovered by a mechanism that was shown to be particularly sensitive to the presence of the inhibitor DIDS $\left(4,4^{\prime}\right.$-diisothiocyanostilbene disulfonic acid). In the presence of amiloride and PSA (picrylsulfonic acid), pHi recovery was also significantly affected. These results indicate that, in the experimental conditions used, $\mathrm{pHi}$ is regulated by the action of an $\mathrm{Na}^{+}$-driven $\mathrm{HCO}_{3}^{-} / \mathrm{Cl}^{-}$exchanger and an $\mathrm{Na}^{+} / \mathrm{HCO}_{3}^{-}$co-transporter and also by the action of the $\mathrm{Na}^{+} / \mathrm{H}^{+}$exchanger. On the other hand, pHi recovery was only slightly affected by concanamycin A, suggesting that $\mathrm{V}$-Type ATPases do not have a relevant action on pHi regulation in human Sertoli cells, and was independent of the presence of bumetanide, suggesting that the inhibition of the $\mathrm{Na}^{+} / \mathrm{K}^{+} / \mathrm{Cl}^{-}$co-transporter does not affect pHi recovery, not even indirectly via the shift of ionic gradients. Finally, $\mathrm{pHi}$ was shown to be sensitive to the removal of external $\mathrm{Cl}^{-}, \mathrm{but}^{\mathrm{n} o t}$ of $\mathrm{Na}^{+}$or $\mathrm{K}^{+}$, evidencing the presence of a membrane $\mathrm{Cl}^{-}$-dependent base extruder, namely the $\mathrm{Na}^{+}$-independent $\mathrm{HCO}_{3}^{-} / \mathrm{Cl}^{-}$ exchanger, and its role on pHi maintenance on these cells.

Reproduction (2009) 137 353-359
\end{abstract}

\section{Introduction}

Sertoli cells face the lumen of the seminiferous tubule, providing structural support and creating an immunologically protected space for germ cells. They facilitate the progression of spermatogenesis and are responsible for the phagocytosis of degenerating germ cells and their remains (Griswold 1995, 1998, Buzzard et al. 2002, Mruk \& Cheng 2004). Sertoli cells provide germ cells with necessary nutrients, hormones, and growth factors and control the composition of the seminiferous fluid (Griswold 1995, Mruk \& Cheng 2004). The effects of testosterone and $\mathrm{FSH}$ on the regulation of the above processes in Sertoli cells are mediated by multiple factors/pathways including intracellular calcium level, protein tyrosine kinases such as MAPKs and Src, receptors for androgen and $\mathrm{FSH}$, cyclic nucleotides, and others (Gorczynska \& Handelsman 1995, Lyng et al. 2000, Von Ledebur et al. 2002, McLachlan et al. 2002, Silva et al. 2002, Walker \& Cheng 2005). Furthermore, it has been reported that intracellular $\mathrm{pH}(\mathrm{pHi})$ regulation is important in cellular response to hormones involved in raising cytosolic $\mathrm{Ca}^{2+}$ (Conlin et al. 1993). In addition, as the control of the $\mathrm{pH}$ of the seminiferous fluid is crucial for male fertility, the $\mathrm{pHi}$ regulation of Sertoli cells should also play a major role in this process (Tuck et al. 1970, Mruk \& Cheng 2004).

This cellular parameter is kept mainly through the net balance between production and elimination of protons and by intracellular buffers (Roos \& Boron 1981). Cells possess in their plasmatic membrane a wide range of ion transporters that participate in $\mathrm{pHi}$ regulation, among which are the basic and acidic particles membrane transporters (Boron 2004). These transporters directly involved on the movement basic and acidic particles across the membrane are classified as acid extruders $\left(\mathrm{Na}^{+}-\mathrm{H}^{+}\right.$exchangers, $\mathrm{Na}^{+}$-driven $\mathrm{HCO}_{3}^{-} / \mathrm{Cl}^{-}$transporters, $\mathrm{Na}^{+} / \mathrm{HCO}_{3}^{-}$co-transporters, and V-ATPases) or acid loaders $\left(\mathrm{Na}^{+}\right.$-independent $\mathrm{HCO}_{3}^{-} / \mathrm{Cl}^{-}$transporters and 
$\mathrm{Na}^{+} / \mathrm{HCO}_{3}^{-}$co-transporters), depending on the direction of movement of those particles (Boron 2004).

The goal of this work was to provide a first assessment on the participation of the different membrane transporters $\left(\mathrm{Na}^{+}-\mathrm{H}^{+}\right.$exchangers, $\mathrm{Na}^{+}$-driven and $\mathrm{Na}^{+}$-independent $\mathrm{HCO}_{3}^{-} / \mathrm{Cl}^{-}$transporters, $\mathrm{Na}^{+} / \mathrm{HCO}_{3}^{-}$ co-transporter, $\mathrm{Na}^{+} / \mathrm{K}^{+} / \mathrm{Cl}^{-}$co-transporters, and $\mathrm{V}$-ATPases) in the regulation of the pHi of human Sertoli cells. The approach used in this study was to follow pHi of cultured human Sertoli cells in $\mathrm{Na}^{+}, \mathrm{K}^{+}$, or $\mathrm{Cl}^{-}$ replete- and free mediums and on pHi recovery in the presence of specific inhibitors (e.g., amiloride, DIDS (4, 4'-diisothiocyanostilbene disulfonic acid), PSA (picrylsulfonic acid), bumetanide, and concanamycin A) after an intracellular acidosis. The acidosis was achieved by adding sodium propionate to cells. To follow the $\mathrm{pHi}$ transients, the $\mathrm{pH}$-sensitive fluorescent probe $2^{\prime}, 7^{\prime}$-bis(2-carboxyethyl) -5-(and-6)-carboxyfluorescein (BCECF) was used.

\section{Results}

\section{pK measurement of BCECF and steady-state average pHi}

The determination of the probe's $\mathrm{p} K$ was performed in vivo using a range of solutions of increasing $\mathrm{pH}$ $(5.5,6.5,7.4,8.0$, and 9.0) to which nigericin $(10 \mu \mathrm{M})$ was added previously. $\mathrm{p} K$ had an average value of $7.01 \pm 0.21(n=3)$. At the conditions used in these experiments $(\mathrm{pHe}=7.4)$, the $\mathrm{pHi}$ of the Sertoli cells averaged $7.05 \pm 0.01(n=45)$.

\section{Acidification and recovery}

Cells equilibrated in Sertoli Ringer were suddenly exposed to sodium propionate Ringer causing a rapid decrease in $\mathrm{pHi}$, corresponding to an average fall of $0.63 \pm 0.01(n=5)$ units (Fig. 1; Table 1). The half-time of the acidification process was $\sim 295 \mathrm{~s}$. Following the acidification, pHi slowly recovered to $100 \%$ of its initial value with an initial recovery rate of $0.0069 \pm 0.0002 \mathrm{pH}$ units/s (Table 1).

\section{Effects of inhibitors on pHi recovery}

Acidification of Sertoli cells with sodium propionate was not significantly affected by the presence of specific inhibitors of some membrane ion transport systems (Figs 1 and 2). Recovery of pHi, however, was altered, although in different degrees, by all the inhibitors used, as can be seen in Table 1 .

DIDS $(0.5 \mathrm{mM})$, an inhibitor of several bicarbonate membrane transporters usually classified as acid extruders, $\mathrm{Na}^{+}$-driven and $\mathrm{Na}^{+}$-independent $\mathrm{HCO}_{3}^{-} / \mathrm{Cl}^{-}$ transporters and $\mathrm{Na}^{+} / \mathrm{HCO}_{3}^{-}$co-transporter, used at concentrations from 0.5 to $1 \mathrm{mM}\left(\mathrm{LD}_{50}=\right.$ not available; $I_{50}=20-200 \mu \mathrm{M}$; GrassI \& Aronson 1986, Helbig et al.

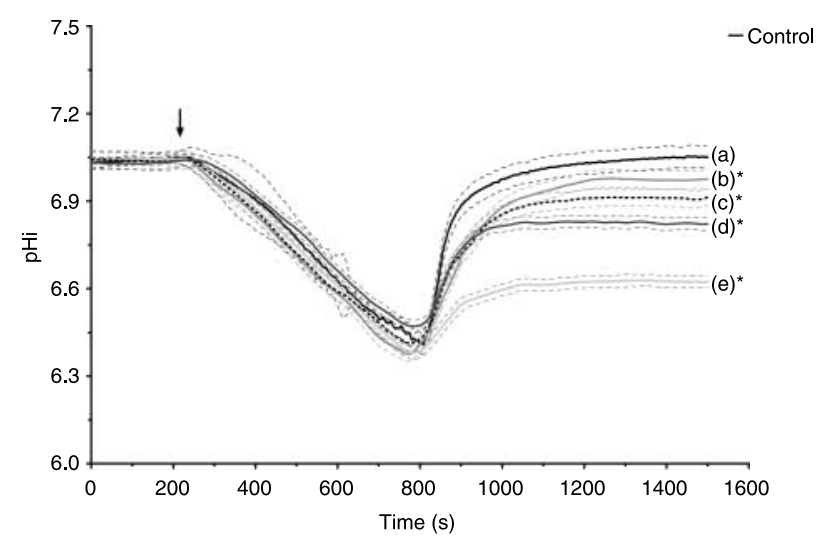

Figure 1 Intracellular $\mathrm{pH}$ of human Sertoli cells acidified with a weak acid in the presence of specific inhibitors. The arrow represents the addition of (a) sodium propionate, (b) sodium propionate and concanamycin A $10 \mu \mathrm{M}$, (c) sodium propionate and PSA $0.5 \mathrm{mM}$, (d) sodium propionate and amiloride $1 \mathrm{mM}$, and (e) sodium propionate and DIDS 0.5 mM. pHi is represented as average \pm S.E.M. $(n=5)$. *Significantly different from control value if $P<0.05$.

1988, Boron 2001) caused the most significant decrease both on the recovery extension (39\% of the initial value) and on the initial recovery rate (Fig. 1; Table 1), supporting the notion that this compound is inhibiting the major transport systems involved in $\mathrm{pHi}$ regulation in Sertoli cells.

Addition of amiloride $(1 \mathrm{mM})$, an inhibitor of the $\mathrm{Na}^{+} / \mathrm{H}^{+}$exchange, used at doses from 0.1 to $1 \mathrm{mM}$ $\left(\mathrm{LD}_{50}\right.$ (rat/oral) $=36-85 \mathrm{mg} / \mathrm{Kg} ; \mathrm{LD}_{50 \text { (mouse/oral) }}=56 \mathrm{mg} / \mathrm{Kg}$; $\mathrm{IC}_{50}=5-25 \mu \mathrm{M}$; Delvaux et al. 1990, Otani et al. 1990, Ahearn et al. 1994, Good \& George 1995, Ahearn et al. 1999), caused a similar decrease on the initial pHi recovery rates (Table 1 ). On the other hand, the recovery extension in the presence of amiloride was significantly lower (56\% of the initial value) than in the presence of DIDS as can be seen in Fig. 1 and Table 1.

PSA $(0.5 \mathrm{mM})$, a specific inhibitor of the $\mathrm{Na}^{+}$-driven $\mathrm{HCO}_{3}^{-} / \mathrm{Cl}^{-}$exchanger, used at the concentration $0.5 \mathrm{mM}$ $\left(\mathrm{LD}_{50}=\right.$ not available; $\mathrm{IC}_{50}=$ not available; Knauf \& Rothstein 1971, Madshus \& Olsnes 1987, Frelin et al. 1988, Marvao et al. 1994), also affected the pHi recovery. Although to a smaller extent than DIDS,

Table 1 Experimental pHi recovery parameters in human Sertoli cells.

\begin{tabular}{lcc}
\hline Inhibitor & pHi recovery $(\%)$ & $\begin{array}{c}\text { pHi recovery rate } \\
\left(10^{3} \mathrm{pH} \text { units/s) }\right.\end{array}$ \\
\hline None & 100 & $6.9 \pm 0.2$ \\
Bumetanide & 100 & $3.6 \pm 0.1^{*}$ \\
Concanamycin A & $95^{*}$ & $1.6 \pm 0.1^{*}$ \\
PSA & $79^{*}$ & $1.3 \pm 0.1^{*}$ \\
Amiloride & $56^{*}$ & $1.2 \pm 0.1^{*}$ \\
DIDS & $39^{*}$ & $1.2 \pm 0.1^{*}$
\end{tabular}

Values are presented as mean \pm S.E.M.; ${ }^{*}$ significantly different from control value if $P<0.05 ; \mathrm{pHi}$ recovery was calculated as the percentage of recovery at steady state after acid load recovery; Initial pHi recovery rate was calculated by linear regression of the data (see Materials and Methods for detail). 


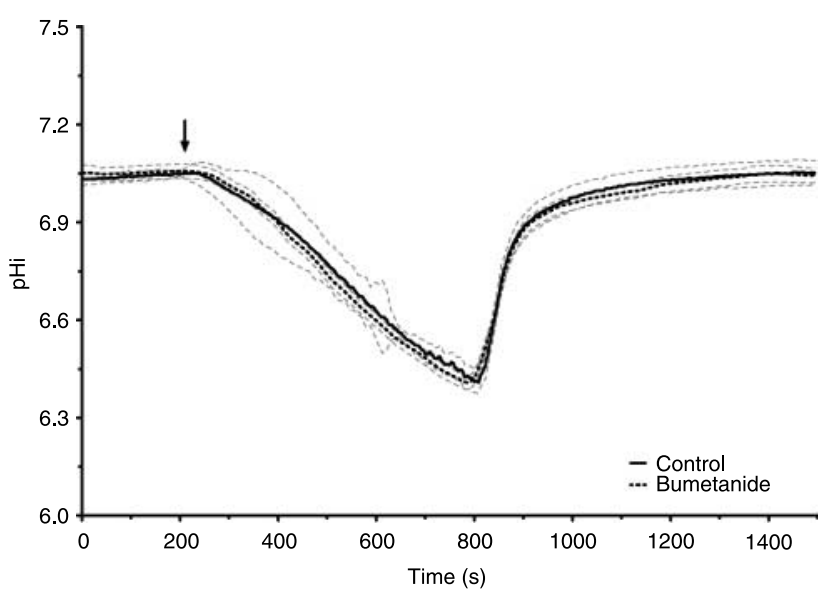

Figure 2 Intracellular $\mathrm{pH}$ of human Sertoli cells acidified with a weak acid in the presence of specific bumetanide. The arrow represents the addition of sodium propionate (black line) or sodium propionate and bumetanide $100 \mu \mathrm{M}$ (dashed line). $\mathrm{pHi}$ is represented as average \pm S.E.M. $(n=5) .{ }^{*}$ Significantly different from control value if $P<0.05$.

which also inhibits this membrane transporter, PSA caused a $21 \%$ decrease in pHi recovery and an $81 \%$ decrease in the initial recovery rate (Fig. 1; Table 1).

Concanamycin $\mathrm{A}(10 \mu \mathrm{M})$, a specific inhibitor of the V-type ATPases, used at concentrations from 1 to $5 \mu \mathrm{M}$ $\left(\mathrm{LD}_{50}\right.$ (mouse/oral) $=21 \mathrm{mg} / \mathrm{Kg} ; \mathrm{IC}_{50}=0.2-0.7 \mu \mathrm{M}$; Muroi et al. 1993, Huss et al. 2002, Oliveira et al. 2004), caused a very small, although significant, decrease in the $\mathrm{pHi}$ recovery extension, as can be seen in Fig. 1 and Table 1. On the other hand, in the presence of this inhibitor the initial pHi recovery rate was significantly lower than in the control situation $(77 \%$ of the initial value; Table 1).

Bumetanide $(10 \mu \mathrm{M})$ was the only inhibitor of a nonacid/base membrane transporter used. Used at the concentration $0.1 \mathrm{mM}$, it specifically inhibits the $\mathrm{Na}^{+}-$ $\mathrm{K}^{+}-\mathrm{Cl}^{-}$co-transporters $\left(\mathrm{LD}_{50}\right.$ (rat/oral) $>6000 \mathrm{mg} / \mathrm{Kg}$; $\mathrm{LD}_{50 \text { (mouse/oral) }}>4000 \mathrm{mg} / \mathrm{Kg}$; $\mathrm{IC}_{50}=0.4-5 \mu \mathrm{M}$; Paris \& Pouyssegur 1986, Vigne et al. 1994, Gamba 2005). The inhibition of this transporter did not affect the $\mathrm{pHi}$ recovery extension, although the initial recovery rate was significantly decrease to $52 \%$ of the control value (Fig. 2; Table 1).

\section{Effects of external $\mathrm{Na}^{+}, \mathrm{K}^{+}$, and $\mathrm{Cl}^{-}$on $\mathrm{pHi}$}

Cytoplasmic $\mathrm{pH}$ was also monitored in the presence and absence of external $\mathrm{Na}^{+}, \mathrm{K}^{+}$, and $\mathrm{Cl}^{-}$. Isosmotic removal of external $\mathrm{Na}^{+}$(by replacement with $\mathrm{K}^{+}$) or $\mathrm{K}^{+}$(by replacement with $\mathrm{Na}^{+}$) did not cause any effects on pHi (Fig. 3). On the other hand, isosmotic removal of $\mathrm{Cl}^{-}$(by replacement with gluconate) caused a rapid increase in pHi of $0.13 \pm 0.02$ units (Fig. 3). Reperfusing of external $\mathrm{Cl}^{-}$caused a recovering of $\mathrm{pHi}$ to values identical of the control situation.

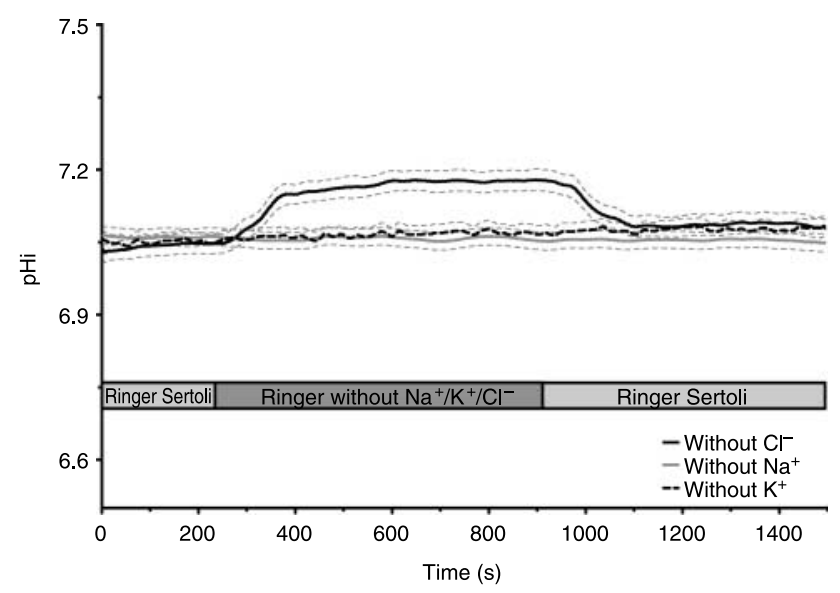

Figure 3 Intracellular $\mathrm{pH}$ of human Sertoli cells acidified with a weak acid in the presence or absence of extracellular $\mathrm{Na}^{+}$(gray line), extracellular $\mathrm{K}^{+}$(dashed line) or extracellular $\mathrm{Cl}^{-}$(black line). The bars represent the removal of the specific ion and the readdition of the ion. $\mathrm{pHi}$ is represented as average \pm S.E.M. $(n=5)$.

\section{Discussion}

Several membrane transport systems participate in $\mathrm{pHi}$ regulation mechanisms and have been classified as acid extruders or acid loaders. Acid extruders require energy to move $\mathrm{H}^{+}$from the cell or to take up $\mathrm{HCO}_{3}^{-}$(Boron 2004). The V-type $\mathrm{H}^{+}$-ATPases (Swallow et al. 1990, Beyenbach \& Wieczorek 2006, Breton \& Brown 2007), the $\mathrm{Na}^{+} / \mathrm{H}^{+}$exchangers (Orlowski \& Grinstein 1997, Counillon \& Pouyssegur 2000), the $\mathrm{Na}^{+}$-driven $\mathrm{HCO}_{3}^{-} / \mathrm{Cl}^{-}$exchangers (Russell \& Boron 1976, Wang et al. 2000), the $\mathrm{Na}^{+} / \mathrm{HCO}_{3}^{-}$exchangers, and the $\mathrm{Na}^{+}$/ $\mathrm{HCO}_{3}^{-}$co-transporter have been classified as acid extruders (Boron 2001, 2004). The so-called acid loaders mediate the exit of weak bases, usually $\mathrm{HCO}_{3}^{-}$or $\mathrm{CO}_{3}^{2-}$, or the entry of $\mathrm{H}^{+}$. The $\mathrm{Na}^{+}$-independent $\mathrm{HCO}_{3}^{-} / \mathrm{Cl}^{-}$ and the electrogenic $\mathrm{Na}^{+} / \mathrm{HCO}_{3}^{-}$exchangers have been classified as acid loaders (Boron 2001, 2004).

The nature of the ion membrane transporters involved in $\mathrm{pHi}$ regulation in Sertoli cell is not very clear in the literature. As the ability of the Sertoli cell to regulate $\mathrm{pHi}$ is an important aspect of its physiology, especially because this cellular parameter may play a major role on the response to hormonal stimulation as well as on the determination of the $\mathrm{pH}$ of the seminiferous fluid, the enlightenment of the participation of diverse membrane transporters on the mechanisms of $\mathrm{pHi}$ regulation in these cells is of great relevance and was the main purpose of this study. For that, cells were loaded with a $\mathrm{pH}$-sensitive fluorescent probe (BCECF) and subjected to an acid load in the presence of specific inhibitors.

Under the experimental conditions used, human Sertoli cells presented a mean value of $\mathrm{pHi}$ of $7.05 \pm 0.01$. Amiloride, a high-affinity inhibitor of the $\mathrm{Na}^{+} / \mathrm{H}^{+}$exchanger (Ahearn et al. 1994, 1999) significantly decreased the $\mathrm{pHi}$ initial recovery rate and extension (Table 1). These results are consistent with the 
participation of the $\mathrm{Na}^{+} / \mathrm{H}^{+}$exchanger on $\mathrm{pHi}$ regulation mechanisms.

DIDS is an inhibitor of several bicarbonate transport systems (Boron et al. 1997, Boron 2001), namely the ones that involve base loading at the expense of the $\mathrm{Na}^{+}$ gradient, such as the $\mathrm{Na}^{+} / \mathrm{HCO}_{3}^{-}$co-transporters and the $\mathrm{Na}^{+}$-driven $\mathrm{HCO}_{3}^{-} / \mathrm{Cl}^{-}$exchanger. In the presence of this inhibitor, the initial pHi recovery rate and recovery extension were drastically reduced (to $17 \%$ of the control value and $39 \%$ of the initial value respectively), therefore we could presuppose that one or both these transporters could be involved in the $\mathrm{pHi}$ regulation after an acid load.

In order to further elucidate the participation of these two bicarbonate transporters on the pHi recovery we used PSA, a specific inhibitor of the $\mathrm{Na}^{+}$-driven $\mathrm{HCO}_{3}^{-}$ $/ \mathrm{Cl}^{-}$exchanger (Knauf \& Rothstein 1971, Madshus \& Olsnes 1987). This compound significantly reduced the $\mathrm{pHi}$ initial recovery rate and recovery extension after the acid load. Therefore, we could assume the presence of the $\mathrm{Na}^{+}$-driven $\mathrm{HCO}_{3}^{-} / \mathrm{Cl}^{-}$exchangers on the membrane of the human Sertoli cells. Nevertheless, the magnitude of the effect of PSA on the recovery extension was much smaller than that of DIDS, suggesting to us the presence of the $\mathrm{Na}^{+} / \mathrm{HCO}_{3}^{-}$co-transporters on the plasma membrane of these cells and their participation in $\mathrm{pHi}$ regulation after an acid load.

Although proton pumps have been described in a wide variety of plasma membranes of acid-secreting epithelial cells (Harvey 1992, Martinez-Zaguilan et al. 1993, Ehrenfeld \& Klein 1997, Rebelo da Costa et al. 1999, Oliveira et al. 2004), its presence has not yet been confirmed in Sertoli cells (Herak-Kramberger et al. 2001). The present study indicates that the $\mathrm{pHi}$ recovery mechanisms in Sertoli cells involve the action of the $\mathrm{H}^{+}$pump, although to a small extent, as a statistically significant difference was observed on initial pHi recovery rate and extension after the acid load, in the presence of concanamycin A, a specific inhibitor of this kind of pump (Huss et al. 2002).

Bumetanide is a specific inhibitor of the $\mathrm{Na}^{+}-\mathrm{K}^{+}-\mathrm{Cl}^{-}$ co-transporter, expressed in a broad spectrum of tissues and implicated in cell volume regulation and in ion transport by secretory epithelial tissue $\left(\mathrm{O}^{\prime}\right.$ Grady et al. 1987), namely in the seminiferous epithelium (Pace et al. 2000). The presence of this inhibitor did not affect the recovery extension of the $\mathrm{pHi}$. As one can see, this membrane transporter is not directly implicated on the extrusion or loading of acid particles thus, unless it had a major role on the maintenance of the intracellular ionic gradients in human Sertoli cells, its effect on $\mathrm{pHi}$ recovery should not be very significant, as is the case. Nevertheless, the presence of bumetanide on the external bathing solution causes a decrease on initial $\mathrm{pHi}$ recovery rate, probably due to the referred disturbance of the intracellular ionic gradients.
Finally, ionic replacement experiments were performed in order to further access on the presence of the several membrane transporters discussed. Only the removal of chloride ion caused a shift to basic values of the basal pHi. Neither the removal of external $\mathrm{Na}^{+}$, nor of $\mathrm{K}^{+}$, caused any effect. The reasoning of these results could be the following: the removal of external $\mathrm{Cl}^{-}$ affected the functioning of either the $\mathrm{Na}^{+}$-independent $\mathrm{HCO}_{3}^{-} / \mathrm{Cl}^{-}$exchanger or the $\mathrm{Na}^{+}$-driven $\mathrm{HCO}_{3}^{-} / \mathrm{Cl}^{-}$ exchanger that will lead to the intracellular accumulation of bicarbonate and consequent rise of $\mathrm{pHi}$.

In conclusion, human Sertoli cells, in the presence of external $\mathrm{Na}^{+}$and bicarbonate, seem to regulate $\mathrm{pHi}$ after an acid load mainly by the action of an $\mathrm{Na}^{+}$-driven $\mathrm{HCO}_{3}^{-} / \mathrm{Cl}^{-}$exchanger and a $\mathrm{Na}^{+} / \mathrm{HCO}_{3}^{-}$co-transporter and also by the action of the $\mathrm{Na}^{+} / \mathrm{H}^{+}$exchanger (Fig. 4). Also, our work, although it suggests the presence in Sertoli cells of V-type ATPases, points to a minor participation on these mechanisms of the regulation of pHi after an acid load. In addition, human Sertoli cells seem to also have on their plasma membranes the $\mathrm{Na}^{+}{ }_{-}$ $\mathrm{K}^{+}-\mathrm{Cl}^{-}$co-transporter, which, as one could expect, does not have a major role on $\mathrm{pHi}$ regulation mechanisms but its absence (inhibition) affects those mechanisms, probably due to ionic gradient alterations.

\section{Materials and Methods}

\section{Chemicals}

BCECF-AM was purchased from Molecular Probes (Carlsbad, CA, USA). Sodium propionate, potassium propionate, nigericin, collagenase, pancreatin, PSA, DNAse, amiloride, DIDS, and concanamycin A were purchased from Sigma. DMEM and Ham's F-12 were purchase from Gibco. Stock solutions of BCECF-AM and concanamycin A were prepared in dimethyl sulfoxide (DMSO) and kept at $20^{\circ} \mathrm{C}$. Stock solutions of nigericin were prepared in ethanol and kept at $20^{\circ} \mathrm{C}$. DMSO and ethanol were always used in concentrations bellow $0.1 \%$ $(\mathrm{v} / \mathrm{v})$. All other chemicals were purchased from Sigma.

(1)

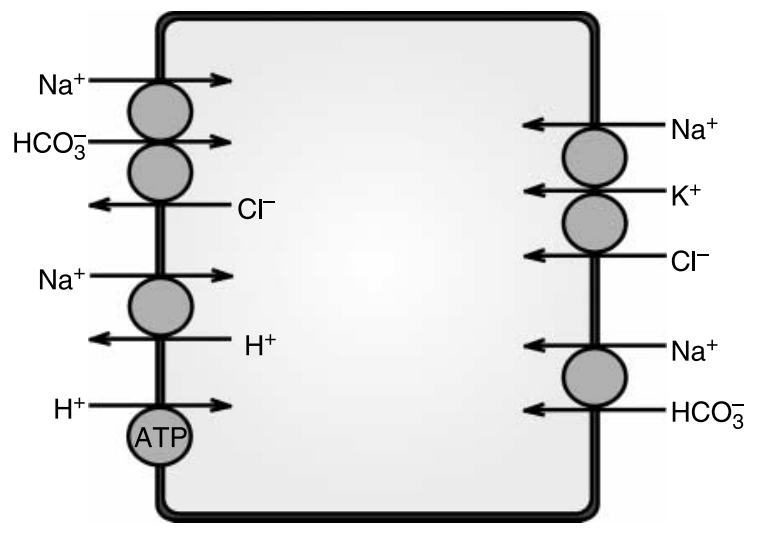

Figure 4 Diagram of the Sertoli cells' membrane transport systems considered. 


\section{Ethical issues}

Human Sertoli cells were obtained from testicular biopsies of infertile patients under treatment for recovery of male gametes at the IVF Unit of the Department of Genetics, Faculty of Medicine and University of Porto.

Patients with normal spermatogenesis were selected. In accordance with the Guidelines of the Local, National and European Ethical Committees, in the present study only cells left in the tissue culture plates after treatment of the patients by intracytoplasmic sperm-spermatid injection were used. In all cases, Sertoli cells were used only after informed patient consent.

\section{Sertoli cell culture}

Each biopsy (0.1 to $0.2 \mathrm{~g}$ ), once obtained, was transferred to sperm preparation medium (SPM; Medicult, Copenhagen, Denmark) containing penicillin and streptomycin until cell isolation.

Sertoli cells were isolated using an adaptation of the enzymatic procedure adapted from the one described by Welsh \& Wiebe (1975), modified by Majumdar et al. (1995) and evaluated by Valdés-González et al. (2005).

Tissue samples were washed twice in cold $\mathrm{HBSS}_{\mathrm{f}}$ (calciumand magnesium-free HBSS, containing $50 \mathrm{U} / \mathrm{ml}$ of penicillin and $50 \mu \mathrm{g} / \mathrm{ml}$ streptomycin sulfate $(\mathrm{pH} \mathrm{7.4))}$ and minced in $\mathrm{HBSS}_{\mathrm{f}}(2.5 \mathrm{ml}$ per $0.1 \mathrm{~g}$ tissue) in a glass-stoppered Erlenmeyer, shaken vigorously during $1 \mathrm{~min}$ to disperse tubules. The tissue was left to settle for 5 min on ice, and the supernatant was discarded. This procedure was repeated twice to mechanically remove red blood cells and free Leydig cells. The resulting pellet was digested in $5 \mathrm{ml}$ of HBSS with collagenase type I (200 U; C0130, Sigma) and DNAse (100 U; D4263, Sigma) continuously shaken (100 r.p.m.) at $32{ }^{\circ} \mathrm{C}$ during $25-35 \mathrm{~min}$. The formed aggregate was removed, washed in $\mathrm{HBSS}_{\mathrm{f}}$ and discarded. The washing $\mathrm{HBSS}_{\mathrm{f}}$ was added to the cellular suspension resulting from the digestion.

The resulting suspension was washed twice and left to settle completely at $4{ }^{\circ} \mathrm{C}$. The resulting pellet was suspended in $5 \mathrm{ml}$ $\mathrm{HBSS}_{\mathrm{f}}$ with $1 \mathrm{mg}$ pancreatin (P3292, Sigma) and DNAse (100 U; D4263) and digested at $32{ }^{\circ} \mathrm{C}$ with continuous shaking (100 r.p.m.) during 15-25 min. The new aggregate formed was discarded and $0.1 \mathrm{ml}$ fetal bovine serum (FBS) was added to the cellular suspension, which was left to rest at $4{ }^{\circ} \mathrm{C}$ for $5 \mathrm{~min}$. The suspension was then centrifuged at $100 \mathrm{~g}$ during $5 \mathrm{~min}$. The pellet was gently suspended in $5 \mathrm{ml} \mathrm{HBSS}_{\mathrm{f}}$. This procedure was repeated twice and the resulting pellet was suspended in $5 \mathrm{ml}$ $\mathrm{HBSS}_{\mathrm{f}}$. This suspension was passed through a glass Pasteur pipette in order to loosen germ cells from the clusters, and then pelleted at $200 \mathrm{~g}$ for $5 \mathrm{~min}$. This procedure was repeated twice. The resulting pellet was suspended Sertoli culture medium (DMEM + Ham's F-12 [HF12]; 1:1, containing $50 \mathrm{U} / \mathrm{ml}$ penicillin and $50 \mu \mathrm{g} / \mathrm{ml}$ streptomycin sulfate, $0.5 \mu \mathrm{g} / \mathrm{ml}$ fungizone, and $5 \%$ heat inactivated FBS) and forced through a $19 \mathrm{G}$ needle, in order to disaggregate large Sertoli clusters.

For culture of Sertoli cells, the concentration of clusters on the cellular suspension obtained from the procedure described above was adjusted to 1000 clusters $/ \mathrm{ml}$ plated on $25 \mathrm{~cm}^{2}$ culture flasks (Cell+, Sarsted), and incubated at $37^{\circ} \mathrm{C}$ in an atmosphere of $5 \% \mathrm{CO}_{2}: 95 \% \mathrm{O}_{2}$. The day of plating was considered day 0 of culture. The cultures were left undisturbed until day 2. Sertoli cell isolation procedures had an average yield of $5 \times 10^{4}$ cell per gram of tissue.

\section{Intracellular $\mathbf{p H}$ measurements}

Cells were loaded with the fluorescent probe during $15 \mathrm{~min}$ at $37{ }^{\circ} \mathrm{C}$ with $1 \mathrm{ml}$ Sertoli Ringer $(\mathrm{NaCl} 130 \mathrm{mM}$; $\mathrm{KCl} 5 \mathrm{mM}$; $\mathrm{MgCl}_{2} 1 \mathrm{mM}$; $\mathrm{CaCl}_{2} 2 \mathrm{mM}$; $\mathrm{NaHCO}_{3} 10 \mathrm{mM}$; Glucose $1 \mathrm{mM}$; HEPES $10 \mathrm{mM}$ (pH 7.4)) containing $1 \mu \mathrm{M}$ BCECF-AM (Molecular Probes). The cells were transferred to the imaging chamber and washed with Sertoli Ringer using a gravity perfusion system $(1 \mathrm{ml} / \mathrm{min})$.

The fluorescence intensities, excited at 490 and $440 \mathrm{~nm}$ (emission $515 \mathrm{~nm}$ ), were continuously measured with an epifluorescence system (DeltaRam, PTI) while the cells were perfused with different solutions.

Background fluorescence was determined at the end of each experiment by removing the cells and perfusing the empty chamber with Sertoli Ringer. The background fluorescence intensity was measured for each wavelength.

The ratios $\left(F_{490} / F_{440}\right)$ were calculated after subtracting the background fluorescence intensities for each measurement at each wavelength.

The calibration procedures were done using the method described by Thomas (1986). In order to convert the fluorescence signals into pHi values, at the end of each protocol a in vivo calibration procedure was performed, using solutions of known pH (5.5 and 9.0), to which nigericin $(10 \mu \mathrm{M})$ was added.

To convert the measured fluorescence ratio (F490/F440) in intracellular $\mathrm{pH}$ values, the following equation was used:

$\mathrm{pH}=\mathrm{p} K+\log \left(\frac{\left(R-R_{\mathrm{A}}\right)}{\left(R_{\mathrm{B}}-R\right)} \times \frac{F_{440}^{\mathrm{Ac}}}{F_{440}^{\mathrm{Bas}}}\right)$

Where $K$ is the BCECF $K_{\mathrm{d}}, R$ is the fluorescence ratio (F490/F440) of the sample, $R_{\mathrm{A}}$ is the fluorescence ratio (F490/F440) of the ( $\mathrm{pH} 5.5)$ solution, $R_{\mathrm{B}}$ is the fluorescence ratio (F490/F440) of the $(\mathrm{pH} 9.0)$ solution, $F_{440}^{\mathrm{Ac}}$ is the fluorescence intensity $(440 \mathrm{~nm})$ of the $(\mathrm{pH} 5.5)$ solution and $F_{440}^{\text {Bas }}$ is the fluorescence intensity $(440 \mathrm{~nm})$ of the $(\mathrm{pH} 9.0)$ solution.

To determine the BCECF $K_{\mathrm{d}}$ value, we performed in vivo measurements of the fluorescence intensity signals emitted at $515 \mathrm{~nm}$, for the excitation wavelengths of 490 and $440 \mathrm{~nm}$, in cells loaded with BCECF and perfused with a series of five calibration solutions of increasing $\mathrm{pH}(5.5,6.5,7.4,8.0$, and 9.0) where nigericin $(10 \mu \mathrm{M})$ was added previously. The $\mathrm{pH}$ data were plotted as a function of

$\log \left(\left(R-R_{\mathrm{A}}\right) /\left(R_{\mathrm{B}}-R\right) \times\left(F_{440}^{\mathrm{AC}} / F_{440}^{\mathrm{Bas}}\right)\right)$

and the value of $\mathrm{p} K$ was estimated from the straight line intercept. 


\section{Intracellular buffering capacity}

In order to characterize changes in $\mathrm{pHi}$, cells were acidified with sodium propionate Ringer $(\mathrm{NaCl} 90 \mathrm{mM}$; $\mathrm{KCl} 5 \mathrm{mM}$; $\mathrm{MgCl}_{2} 1 \mathrm{mM} ; \mathrm{CaCl}_{2} 2 \mathrm{mM} ; \mathrm{NaHCO}_{3} 10 \mathrm{mM}$; glucose $1 \mathrm{mM}$; HEPES $10 \mathrm{mM}$; $40 \mathrm{mM}$ sodium propionate $(\mathrm{pH} 7.4))$ or potassium propionate Ringer $\left(\mathrm{KCl} 95 \mathrm{mM} ; \mathrm{MgCl}_{2} 1 \mathrm{mM}\right.$; $\mathrm{CaCl}_{2} 2 \mathrm{mM}$; $\mathrm{KHCO}_{3} 10 \mathrm{mM}$; glucose $1 \mathrm{mM}$; HEPES $10 \mathrm{mM}$; $40 \mathrm{mM}$ potassium propionate $(\mathrm{pH}$ 7.4)). At physiological $\mathrm{pH}$, propionate is in equilibrium with its non-ionized form propionic acid that rapidly diffuses into the cell and promptly ionizes causing an intracellular acidosis. The response to this intracellular acid load was followed in time.

The cells were initially perfused with Sertoli Ringer and, after a steady-state period of $180 \mathrm{~s}$, the propionate was added. The subsequent alkalinization ( $\mathrm{pHi}$ recovery) of the cells was followed in the presence or absence of specific inhibitors (amiloride $1 \mathrm{mM}$, bumetanide $100 \mu \mathrm{M}$, DIDS $0.5 \mathrm{mM}$, PSA $0.5 \mathrm{mM}$, and concanamycin A $10 \mu \mathrm{M}$ ).

\section{Effect of external ion removal on pHi}

The cells were initially perfused with Sertoli Ringer and, after a steady-state period of $180 \mathrm{~s}, \mathrm{Na}^{+}, \mathrm{K}^{+}$, or $\mathrm{Cl}^{-}$were removed from the external medium and replaced isosmotically by $\mathrm{K}^{+}$, $\mathrm{Na}^{+}$, or gluconate respectively. Sodium-free medium was composed by $\mathrm{KCl} 135 \mathrm{mM}, \mathrm{MgCl}_{2} 1 \mathrm{mM}, \mathrm{CaCl}_{2} 2 \mathrm{mM}$, $\mathrm{KHCO}_{3} 10 \mathrm{mM}$, glucose $1 \mathrm{mM}$, HEPES $10 \mathrm{mM}$ (pH 7.4). Potassium free-medium was composed by $\mathrm{NaCl} 135 \mathrm{mM}$, $\mathrm{MgCl}_{2} 1 \mathrm{mM}, \mathrm{CaCl}_{2} 2 \mathrm{mM}, \mathrm{NaHCO}_{3} 10 \mathrm{mM}$, glucose $1 \mathrm{mM}$, HEPES $10 \mathrm{mM}$ (pH 7.4). Chloride free-medium was composed by sodium gluconate $130 \mathrm{mM}$, potassium gluconate $135 \mathrm{mM}$, magnesium gluconate $1 \mathrm{mM}$, calcium gluconate $2 \mathrm{mM}$, $\mathrm{NaHCO}_{3} 10 \mathrm{mM}$, glucose $1 \mathrm{mM}$, HEPES $10 \mathrm{mM}$ (pH 7.4). The $\mathrm{pHi}$ of the cells was followed in the presence or absence of the specific ions.

\section{Analysis of results}

All data are presented as arithmetic means \pm S.E.M. of five replicates of five different biopsies. The initial pHi recovery rate was determined by linear regression of the data.

For statistical analysis a one-way ANOVA was performed followed by a Dunn's multiple comparison test. Results were considered significantly different from control value if $P<0.05$.

\section{Declaration of interest}

The authors declare that there is no conflict of interest that could be perceived as prejudicing the impartiality of the research reported.

\section{Funding}

P F Oliveira was supported by Fundação para a Ciência e a Tecnologia (SFRH/BPD/20965/2004).

\section{References}

Ahearn GA, Zhuang Z, Duerr J \& Pennington V 1994 Role of the invertebrate electrogenic $2 \mathrm{Na}^{+} / 1 \mathrm{H}^{+}$antiporter in monovalent and divalent cation transport. Journal of Experimental Biology 196 319-335.

Ahearn GA, Duerr JM, Zhuang Z, Brown RJ, Aslamkhan A \& Killebrew DA 1999 Ion transport processes of crustacean epithelial cells. Physiological and Biochemical Zoology 72 1-18.

Beyenbach KW \& Wieczorek H 2006 The V-type $\mathrm{H}^{+}$ATPase: molecular structure and function, physiological roles and regulation. Journal of Experimental Biology 209 577-589.

Boron WF 2001 Sodium-coupled bicarbonate transporters. Journal of the Pancreas 2 176-181.

Boron WF 2004 Regulation of intracellular pH. Advances in Physiology Education 28 160-179.

Boron WF, Fong P, Hediger MA, Boulpaep EL \& Romero MF 1997 The electrogenic $\mathrm{Na} / \mathrm{HCO}_{3}$ cotransporter. Wiener Klinische Wochenschrift 109 445-456.

Breton S \& Brown D 2007 New insights into the regulation of V-ATPasedependent proton secretion. American Journal of Physiology. Renal Physiology 292 F1-F10.

Buzzard JJ, Wreford NG \& Morrison JR 2002 Marked extension of proliferation of rat Sertoli cells in culture using recombinant human FSH. Reproduction 124 633-641.

Conlin PR, Cirillo M, Zerbini G, Williams GH \& Canessa ML 1993 Calcium-mediated intracellular acidification and activation of $\mathrm{Na}(+)$ $\mathrm{H}^{+}$exchange in adrenal glomerulosa cells stimulated with potassium. Endocrinology 132 1345-1352.

Counillon L \& Pouyssegur J 2000 The expanding family of eucaryotic $\mathrm{Na}(+) / \mathrm{H}(+)$ exchangers. Journal of Biological Chemistry 275 1-4.

Delvaux M, Bastie MJ, Chentoufi J, Cragoe EJJr Jr, Vaysse N \& Ribet A 1990 Amiloride and analogues inhibit $\mathrm{Na}(+)-\mathrm{H}^{+}$exchange and cell proliferation in AR42J pancreatic cell line. American Journal of Physiology 259 G842-G849.

Ehrenfeld J \& Klein U 1997 The key role of the $\mathrm{H}^{+}$V-ATPase in acidbase balance and $\mathrm{Na}^{+}$transport processes in frog skin. Journal of Experimental Biology 200 247-256.

Frelin C, Vigne P, Ladoux A \& Lazdunski M 1988 The regulation of the intracellular $\mathrm{pH}$ in cells from vertebrates. European Journal of Biochemistry 174 3-14.

Gamba G 2005 Molecular physiology and pathophysiology of electroneutral cation-chloride cotransporters. Physiological Reviews 85 423-493.

Good DW \& George T 1995 Basolateral membrane $\mathrm{Na}^{+} / \mathrm{H}^{+}$exchange enhances $\mathrm{HCO}_{3}^{-}$absorption in rat medullary thick ascending limb: evidence for functional coupling between basolateral and apical membrane $\mathrm{Na}^{+} / \mathrm{H}^{+}$exchangers. PNAS 92 12525-12529.

Gorczynska E \& Handelsman DJ 1995 Androgens rapidly increase the cytosolic calcium concentration in Sertoli cells. Endocrinology 136 2052-2059.

Grassl SM \& Aronson PS $1986 \mathrm{Na}^{+} / \mathrm{HCO}_{3}$-CO-transport in basolateral membrane vesicles isolated from rabbit renal cortex. Journal of Biological Chemistry 261 8778-8783.

Griswold MD 1995 Interactions between germ cells and Sertoli cells in the testis. Biology of Reproduction 52 211-216.

Griswold MD 1998 The central role of Sertoli cells in spermatogenesis. Seminars in Cell and Developmental Biology 9 411-416.

Harvey BJ 1992 Energization of sodium absorption by the $\mathrm{H}(+)$-ATPase pump in mitochondria-rich cells of frog skin. Journal of Experimental Biology 172 289-309.

Helbig H, Korbmacher C, Kuhner D, Berweck S \& Wiederholt M 1988 Characterization of $\mathrm{Cl}^{-} / \mathrm{HCO}_{3}^{-}$exchange in cultured bovine pigmented ciliary epithelium. Experimental Eye Research 47 515-523.

Herak-Kramberger CM, Breton S, Brown D, Kraus O \& Sabolic I 2001 Distribution of the vacuolar $\mathrm{H}^{+}$ATPase along the rat and human male reproductive tract. Biology of Reproduction 64 1699-1707.

Huss M, Ingenhorst G, Konig S, Gassel M, Drose S, Zeeck A, Altendorf K \& Wieczorek H 2002 Concanamycin A, the specific inhibitor of V-ATPases, binds to the $\mathrm{V}(\mathrm{o})$ subunit c. Journal of Biological Chemistry 277 40544-40548. 
Knauf PA \& Rothstein A 1971 Chemical modification of membranes: II. Permeation paths for sulfhydryl agents. Journal of General Physiology $\mathbf{5 8}$ 211-223.

Von Ledebur EI, Almeida JP, Loss ES \& Wassermann GF 2002 Rapid effect of testosterone on rat Sertoli cell membrane potential. Relationship with $\mathrm{K}^{+}$ATP channels. Hormone and Metabolic Research 34 550-555.

Lyng FM, Jones GR \& Rommerts FF 2000 Rapid androgen actions on calcium signaling in rat sertoli cells and two human prostatic cell lines: similar biphasic responses between 1 picomolar and 100 nanomolar concentrations. Biology of Reproduction 63 736-747.

Madshus IH \& Olsnes S 1987 Selective inhibition of sodium-linked and sodium-independent bicarbonate/chloride antiport in Vero cells. Journal of Biological Chemistry 262 7486-7491.

Majumdar SS, Tsuruta J, Griswold MD \& Bartke A 1995 Isolation and culture of Sertoli cells from the testes of adult Siberian hamsters: analysis of proteins synthesized and secreted by Sertoli cells cultured from hamsters raised in a long or a short photoperiod. Biology of Reproduction 52 658-666.

Martinez-Zaguilan R, Lynch RM, Martinez GM \& Gillies RJ 1993 Vacuolartype $\mathrm{H}(+)$-ATPases are functionally expressed in plasma membranes of human tumor cells. American Journal of Physiology 265 C1015-C1029.

Marvao P, Emilio M, Ferreira K, Fernandes P \& Ferreira H 1994 Ion transport in the intestine of Anguilla Anguilla: gradients and translocators. Journal of Experimental Biology 193 97-117.

McLachlan RI, O'Donnell L, Meachem SJ, Stanton PG, de Kretser DM, Pratis K \& Robertson DM 2002 Identification of specific sites of hormonal regulation in spermatogenesis in rats, monkeys, and man. Recent Progress in Hormone Research 57 149-179.

Mruk DD \& Cheng CY 2004 Sertoli-Sertoli and Sertoli-germ cell interactions and their significance in germ cell movement in the seminiferous epithelium during spermatogenesis. Endocrinology Reviews 25 747-806.

Muroi M, Shiragami N, Nagao K, Yamasaki M \& Takatsuki A 1993 Folimycin (concanamycin A), a specific inhibitor of V-ATPase, blocks intracellular translocation of the glycoprotein of vesicular stomatitis virus before arrival to the Golgi apparatus. Cell Structure and Function 18 139-149.

O'Grady SM, Palfrey HC \& Field M 1987 Characteristics and functions of $\mathrm{Na}-\mathrm{K}-\mathrm{Cl}$ cotransport in epithelial tissues. American Journal of Physiology 253 C177-C192.

Oliveira PF, Lopes IA, Barrias C \& Rebelo da Costa AM $2004 \mathrm{H}^{+}$-ATPase of crude homogenate of the outer mantle epithelium of Anodonta cygnea. Comparative Biochemistry and Physiology. Part A, Molecular \& Integrative Physiology 139 425-432.

Orlowski J \& Grinstein S $1997 \mathrm{Na}^{+} / \mathrm{H}^{+}$exchangers of mammalian cells. Journal of Biological Chemistry 272 22373-22376.

Otani H, Otani H, Uriu T, Hara M, Inoue $M$, Omori K, Cragoe EJ Jr \& Inagaki C 1990 Effects of inhibitors of protein kinase $\mathrm{C}$ and $\mathrm{Na}^{+} / \mathrm{H}^{+}$ exchange on alpha 1-adrenoceptor-mediated inotropic responses in the rat left ventricular papillary muscle. British Journal of Pharmacology $\mathbf{1 0 0}$ 207-210.

Pace AJ, Lee E, Athirakul K, Coffman TM, O'Brien DA \& Koller BH 2000 Failure of spermatogenesis in mouse lines deficient in the $\mathrm{Na}(+)-\mathrm{K}(+)-$ $2 \mathrm{Cl}(-)$ cotransporter. Journal of Clinical Investigation 105 441-450.

Paris S \& Pouyssegur J 1986 Growth factors activate the bumetanidesensitive $\mathrm{Na}^{+} / \mathrm{K}^{+} / \mathrm{Cl}^{-}$cotransport in hamster fibroblasts. Journal of Biological Chemistry 261 6177-6183.

Rebelo da Costa AM, Oliveira PF, Barrias C \& Ferreira HG 1999 Identification of a V-type proton pump in the outer mantle epithelium of Anodonta cygnea. Comparative Biochemistry and Physiology. Part A, Molecular \& Integrative Physiology 123 337-342.

Roos A \& Boron WF 1981 Intracellular pH. Physiological Reviews 61 296-434.

Russell JM \& Boron WF 1976 Role of choloride transport in regulation of intracellular $\mathrm{pH}$. Nature 264 73-74.

Silva FR, Leite LD \& Wassermann GF 2002 Rapid signal transduction in Sertoli cells. European Journal of Endocrinology 147 425-433.

Swallow CJ, Grinstein S \& Rotstein OD 1990 A vacuolar type H(+)-ATPase regulates cytoplasmic $\mathrm{pH}$ in murine macrophages. Journal of Biological Chemistry 265 7645-7654.

Thomas JA 1986 Intracellularly trapped pH indicators. Society of General Physiologists Series 40 311-325.

Tuck RR, Setchell BP, Waites GM \& Young JA 1970 The composition of fluid collected by micropuncture and catheterization from the seminiferous tubules and rete testis of rats. Pflügers Archiv 318 225-243.

Valdes-Gonzalez R, Silva-Torres L, Ramirez-Gonzalez B, Ormsby CE, Teran-Ortiz L \& Ayala-Sumuano JT 2005 Method for evaluating quality of cultured neonatal pig Sertoli cells. Xenotransplantation 12 316-323.

Vigne P, Lopez Farre A \& Frelin C $1994 \mathrm{Na}(+)-\mathrm{K}(+)-\mathrm{Cl}$ - cotransporter of brain capillary endothelial cells. Properties and regulation by endothelins, hyperosmolar solutions, calyculin A, and interleukin-1. Journal of Biological Chemistry 269 19925-19930.

Walker WH \& Cheng J 2005 FSH and testosterone signaling in Sertoli cells. Reproduction 130 15-28.

Wang CZ, Yano $\mathbf{H}$, Nagashima K \& Seino S 2000 The $\mathrm{Na}^{+}$-driven $\mathrm{Cl}^{-} /$ $\mathrm{HCO}_{3}^{-}$exchanger. Cloning, tissue distribution, and functional characterization. Journal of Biological Chemistry 275 35486-35490.

Welsh MJ \& Wiebe JP 1975 Rat sertoli cells: a rapid method for obtaining viable cells. Endocrinology 96 618-624.

Received 24 August 2008

First decision 8 October 2008

Revised manuscript received 18 November 2008

Accepted 21 November 2008 